\title{
ATP-Induced Non-Neuronal Cell Permeabilization in the Rat Inner Retina
}

\author{
Barbara Innocenti, ${ }^{1,2 *}$ Sylke Pfeiffer, ${ }^{1 *}$ Eberhart Zrenner, ${ }^{1}$ Konrad Kohler, ${ }^{1}$ and Elke Guenther ${ }^{1,3}$ \\ ${ }^{1}$ Laboratory of Cell Physiology and Molecular Biology, Department of Experimental Ophthalmology, University Eye Hospital, D-72076 Tuebingen, \\ Germany, ${ }^{2}$ Department of Neurobiology and Anatomy, University of Texas Health Science Center at Houston, Houston, Texas 77030, and ${ }^{3}$ Natural and \\ Medical Sciences Institute (NMI) at the University Tuebingen, D-72770 Reutlingen, Germany
}

The $\mathrm{P} 2 \mathrm{X}_{7}$ subtype holds a special position among $\mathrm{P} 2 \mathrm{X}$ receptors because of its ability to act both as a classical, ligand-gated ion channel, and as a permeabilization pore that can induce cell death under prolonged activation by ATP.

We have shown previously that, in rat retina, $\mathrm{P} 2 \mathrm{X}_{7}$ receptors are located in the inner nuclear layer and ganglion cell layer (GCL). The present study was aimed at finding whether retinal $\mathrm{P} 2 \mathrm{X}_{7}$ receptors can act as a mediator of cell permeabilization and, if so, at identifying the cellular target(s) of this effect.

As an indicator of cell permeabilization, we used the fluorescent dye Y0-PRO-1 (molecular weight, 375 Da), which enters cells only through large pores like those opened by prolonged or sustained stimulation of $\mathrm{P} 2 \mathrm{X}_{7}$ receptors and binds to DNA, providing a stable labeling of the activated cells.

Different agonists for $\mathrm{P} 2$ receptors were tested for their ability to cause cell permeabilization in flat-mounted rat retinas. Among them, only high concentrations of ATP $(500 \mu \mathrm{M})$ and BzATP $\left(2^{\prime}, 3^{\prime}\right.$-0-(4-benzoyl-benzoyl)-ATP triethylammonium) (100 $\left.\mu \mathrm{M}\right)$ were able to induce accumulation of YO-PRO-1 in the GCL and in the nerve fiber layer, suggesting that different cell types were responding to $\mathrm{P} 2 \mathrm{X}_{7}$ stimulation. This effect was blocked by the P2 antagonists suramin and PPADS (pyridoxal-phosphate-6-azophenyl-2' $4^{\prime}$-disulfonic acid) and by the $\mathrm{P} 2 \mathrm{X}_{7}$-selective inhibitor Brilliant Blue $\mathrm{G}$.

To identify the retinal cell types affected by ATP-induced permeabilization, we used in vivo labeling techniques. Our data clearly reveal that prolonged stimulation of $\mathrm{P} 2 \mathrm{X}_{7}$ receptors elicits permeabilization exclusively in microglial cells but not in neurons of the inner retina.

Key words: ATP; $\mathrm{P}_{2} \mathrm{X}_{7}$; purinergic receptors; retinal neurotransmission; microglia; ganglion cells

\section{Introduction}

Besides being the universal cellular energy source, ATP is a key extracellular signaling molecule whose role was inferred long before cloning of the receptors that mediate its effects. Nowadays, these receptors have been assigned to a large family, the P2 receptors, comprising P2Ys, G-protein-coupled receptors, and P2Xs, ligand-gated ionic channels (Ralevic and Burnstock, 1998).

Despite the knowledge that ATP is released during physiological and pathological events in the mammalian retina, our understanding of the role of this neurotransmitter and its actions in the retina is still minimal.

Compelling evidence has been accumulated that ATP exerts a modulatory effect on retinal neurotransmission (Neal and Cunningham, 1994; Neal et al., 1998). Moreover, stimulation of ret-

Received July 13, 2004; revised Aug. 13, 2004; accepted Aug. 17, 2004.

This work was supported by European Union Grant HPRN-CT-2000-00098, German Research Council Grant GU 259/11-1/2, and Grimmke Foundation. We thank Gudrun Haerer for excellent technical assistance, Prof. Andreas Reichenbach for providing Cy3-coupled ILB-4, Dr. Francesco Di Virgilio and Julian A. Barden for providing different $\mathrm{P} 2 \mathrm{X}_{7}$ antibodies, and Thomas Rice for manuscript suggestions.

*B.I. and S.P. contributed equally to the experimental part of this study.

Correspondence should be addressed to Barbara Innocenti, Department of Neurobiology and Anatomy, University of Texas-Houston Medical School, MSB 7.046, 6431 Fannin Street, Houston, TX 77030. E-mail: barbara.innocenti@uth.tmc.edu.

DOI:10.1523/JNEUROSCI.2812-04.2004

Copyright $\odot 2004$ Society for Neuroscience $\quad$ 0270-6474/04/248577-07\$15.00/0 inal glial cells in situ evokes an increase in extracellular ATP, accompanied by the spreading of a calcium wave among adjacent glial cells; this in turn affects the firing rate of neighboring neurons (Newman and Zahs, 1997, 1998; Newman, 2001). Primary culture preparations have made it possible to identify cholinergic neurons, retinal ganglion cells (RGCs), astrocytes, Muller cells, and oligodendrocytes as cellular targets of extracellular ATP (Neal and Cunningham, 1994; Kirischuk et al., 1995; Keirstead and Miller, 1997; Newman and Zahs, 1997, 1998; Neal et al., 1998; Taschenberger et al., 1999; Pannicke et al., 2000). We performed a first systematic study of the expression and distribution of different types of ATP receptors in the retina and found that both $\mathrm{P} 2 \mathrm{X}$ and $\mathrm{P} 2 \mathrm{Y}$ subunits are expressed in identified adult retinal cell types, such as bipolar cells, Muller cells, and RGCs (Braendle et al., 1998a,b; Jabs et al., 2000; Wheeler-Schilling et al., 2000, 2001).

Among these, one specific subunit attracted our attention, namely $\mathrm{P} 2 \mathrm{X}_{7} . \mathrm{P}_{2} \mathrm{X}_{7}$ is not only a nonselective cationic channel like other $\mathrm{P} 2 \mathrm{X}$ receptors, but, under prolonged or sustained stimulation by ATP, it can also expand and form a large pore in the cell membrane. This pore is permeable to molecules up to $900 \mathrm{Da}$. This $\mathrm{P} 2 \mathrm{X}_{7}$-mediated cell permeabilization can lead to cell death, as has been shown for many cell types in the immune system (Di Virgilio et al., 2001).

In our previous studies performed on adult rat retina, $\mathrm{P} 2 \mathrm{X}_{7}$ 
was detected in identified RGCs (Braendle et al., 1998b), and labeling was clearly seen in the inner nuclear layer (INL) and ganglion cell layer (GCL), indicating that both RGCs and subpopulations of amacrine cells express this subunit. Because full activation of $\mathrm{P}_{2} \mathrm{X}_{7}$ receptors may have a deleterious effect on the complex retinal electrical circuits, the aim of the present study was to assess whether these receptors were functional and endowed with the ability to induce permeabilization of retinal cells. We were especially interested in learning whether the massive RGC death found during normal retinal development can be attributed to the permeabilizing ability of the $\mathrm{P} 2 \mathrm{X}_{7}$ receptor.

Using fluorescence assays of cell permeabilization, our study clearly showed that, although RGCs are endowed with $\mathrm{P}_{2} \mathrm{X}_{7}$ receptors, the latter never promotes the opening of permeabilizing pores. Instead, prolonged $\mathrm{P}_{2} \mathrm{X}_{7}$ stimulation induced permeabilization of microglial cells located in the vicinity of RGCs.

\section{Materials and Methods \\ Animals}

Pigmented brown Norway rats between postnatal day 2 (P2) and P17 were used for all of the experiments. The animals were killed by decapitation under ether anesthesia. Their eyes were removed, the anterior poles were dissected, and the retinas were isolated.

For physiological experiments, the retinas were stored in oxygenated $\left(95 \% \mathrm{O}_{2}-5 \% \mathrm{CO}_{2}\right)$ Ames' medium, at $32^{\circ} \mathrm{C}$, until use.

\section{Fluorescence imaging}

Experiments were performed with an upright microscope (BX50WI Olympus Optical, Tokyo, Japan) equipped for epifluorescence microscopy. Excitation light $(480 \mathrm{~nm})$ was provided by a monochromator (T.I.L.L. Photonics, Martinsried, Germany) and delivered to the sample through a quartz fiber and a $40 \times$ water immersion objective. Fluorescence emission was collected through a dichroic mirror (500 dichroic long-pass) and filtered with a 515 long-pass filter. Light was detected using a CCD Camera (TILL IMAGO; T.I.L.L. Photonics, Martinsried, Germany).

The retinas were continuously perfused with saline containing the following (in mM): $117 \mathrm{NaCl}, 3 \mathrm{KCl}, 0.3 \mathrm{CaCl}_{2}, 15$ glucose, $0.5 \mathrm{NaH}_{2} \mathrm{PO}_{4}$, and $26 \mathrm{NaHCO}_{3}$ (bubbled with $5 \% \mathrm{CO}_{2}$ ).

ATP, 2', 3'-O-(4-benzoyl-benzoyl)-ATP triethylammonium (BzATP) $(100 \mu \mathrm{M})$, YO-PRO-1 $(1.5 \mu \mathrm{M})$, and all the other agonists $(1 \mathrm{mM})$ and antagonists $(100 \mu \mathrm{M})$ were applied from a pipette $(0.1 \mathrm{~mm})$ connected to a valve-controlled superfusion system (DAD-12; ALA Scientific Instruments, Westbury, NY).

\section{In vivo retinal cell labeling}

Nuclei. The nuclei were labeled in vivo by incubating the intact retina at room temperature with the cell membrane-permeable dye Hoechst $33342(10 \mu \mathrm{g} / \mathrm{ml})$ for $10 \mathrm{~min}$ after enzymatic treatment with collagenasedispase $(2 \mathrm{mg} / \mathrm{ml})$ plus DNase $(100 \mathrm{mg} / \mathrm{ml})(5 \mathrm{~min})$.

Retinal ganglion cells. Crystals of micro-ruby were deposited on the optic nerve stump of isolated eyeballs. After $15 \mathrm{~min}$, the crystals were washed out, and the retinas were dissected and stored for $2 \mathrm{hr}$ at $32^{\circ} \mathrm{C}$. This time interval allowed retrograde transport of the dye along the nerve fibers to the cell bodies in the GCL. Alternatively, red fluorescent beads (Lumafluor, Naples, FL) were injected into the superior colliculus of P1 animals.

Muller cells. Muller cell end feet were labeled by perfusing for $5 \mathrm{~min}$ with the dye Mitotracker Red dissolved in extracellular saline (10 $\mathrm{mg} / \mathrm{ml}$ ).

Microglia. Microglia were labeled by incubation for $1 \mathrm{hr}$ in Cy3- conjugated isolectin B4 (ILB-4) $(20 \mu \mathrm{g} / \mathrm{ml}$; generous gift from Prof. A. Reichenbach, University of Leipzig, Leipzig, Germany) after enzymatic treatment with collagenase-dispase $(2 \mathrm{mg} / \mathrm{ml})$ plus DNase $(100 \mathrm{mg} / \mathrm{ml})$ (5 min).

\section{Immunohistochemistry}

Retinas from Brown Norway rats at different developmental stages between P2 and P14 were used. Retinas were fixed for $20 \mathrm{~min}$ in $4 \%(\mathrm{w} / \mathrm{v})$ paraformaldehyde in phosphate buffer $(\mathrm{PB})(0.1 \mathrm{M}), \mathrm{pH} 7.4$, at $4^{\circ} \mathrm{C}$. After washing in $\mathrm{PB}$, tissues were cryoprotected by successive immersions for $10 \mathrm{~min}$ in $10 \%(\mathrm{w} / \mathrm{v})$ and $20 \%$ sucrose in $\mathrm{PB}$ and finally stored overnight at $4^{\circ} \mathrm{C}$ in $30 \%$ sucrose. Samples were then embedded in a tissue-freezing medium (Jung; Leica, Heidelberg, Germany), sectioned vertically into 14 $\mu \mathrm{m}$ slices with a cryostat, and collected on gelatin-coated slides.

Sections were incubated for $1 \mathrm{hr}$ with $10 \%$ normal goat serum (NGS) (Sigma, Munich, Germany) and $0.3 \%$ Triton X-100 in PBS (PBST) to reduce background staining. The $\mathrm{P} 2 \mathrm{X}_{7}$ subunit antibody (Chemicon, Hofheim, Germany) was diluted (1:250) in PBST containing 10\% NGS and incubated overnight at $4^{\circ} \mathrm{C}$. After being washed with PBS, the samples were incubated for $1 \mathrm{hr}$ with Alexa 488 (dilution 1:1500; Mo Bi Tec, Goettingen, Germany) in PBST with 5\% NGS.

Similar immunostaining pattern was obtained with at least two other different antibodies kindly provided by Dr. F. Di Virgilio (University of Ferrara, Ferrara, Italy) and J. A. Barden (University of Sydney, Sydney, Australia).

\section{Reagents and antibodies}

All of the reagents used were of analytical grade. ATP, adenosine $5^{\prime}-O$ (3-thiotriphosphate) (ATP $\gamma \mathrm{S}), 2^{\prime}-3^{\prime}$-O-(4-benzoylbenzoyl)adenosine $5^{\prime}$-triphosphate triethylammonium salt, UDP, ADP, suramin, pyridoxal-phosphate-6-azophenyl-2', $4^{\prime}$-disulfonic acid (PPADS), $2^{\prime}, 3^{\prime}$ dialdehyde ATP [oxidized ATP (OzATP)], and Brilliant Blue G were from Sigma. YO-PRO-1 iodide, micro-ruby, and Mitotracker Red were obtained from Molecular Probes (Mo Bi Tec, Goettingen, Germany).

\section{Results}

\section{$\mathrm{P} 2 \mathrm{X}_{7}$ expression in the rat retina}

To show that $\mathrm{P}_{2} \mathrm{X}_{7}$ is not only expressed in the adult rat retina (Braendle et al., 1998b) but also at the ages when the physiological experiments of the present study were performed, we performed immunocytochemical experiments on vertical retinal slices of P2-P14 animals.

As Figure $1 A$ shows, immunoreactivity (IR) for $\mathrm{P}_{2} \mathrm{X}_{7}$ was observed as early as P2. At this age, almost all cells in the GCL and in the inner part of the neuroblastic layer $(\mathrm{NBL})$ were clearly labeled. Other immunoreactive cells were located in the outer part of the NBL and seemed to be distributed in one row (arrows).

Many cells in the GCL were labeled at P7 (Fig. $1 B$ ), suggesting that RGC and/or amacrine cells expressed $\mathrm{P} 2 \mathrm{X}_{7}$ receptors. Labeling in the inner plexiform layer (IPL) was either diffuse or was clustered into three defined layers. In the INL, P2X $\mathrm{X}_{7}$-positive cells 
A
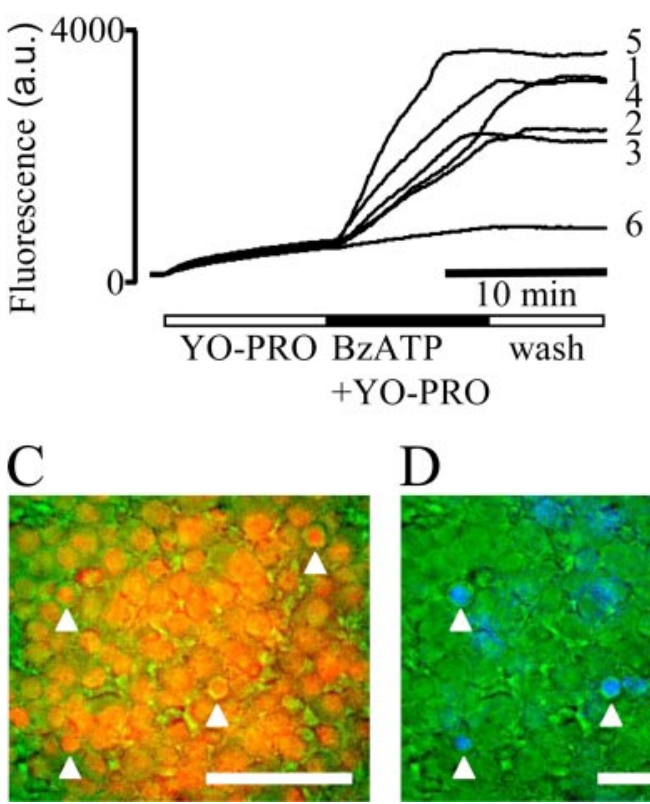

B

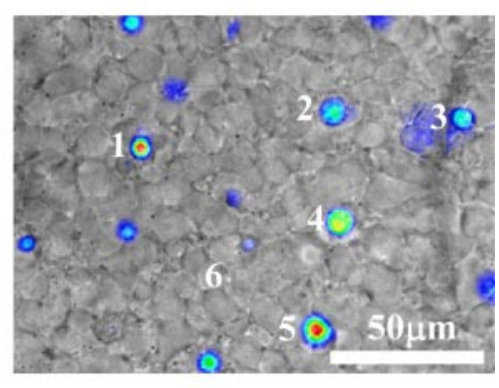

E

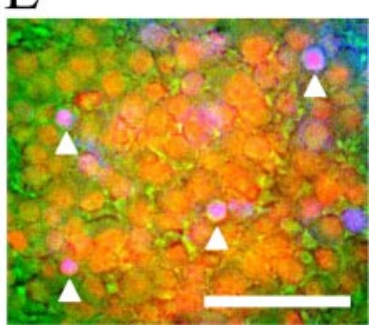

Figure 2. BzATP-induced cell permeabilization in the rat inner retina. A shows the kinetics of Y0-PR0-1 (1.5 $\mu \mathrm{M})$ uptake in rat flat-mount retina exposed to prolonged stimulation with BzATP (10 min, $100 \mu \mathrm{M})$. B shows the pattern of Y0-PRO- 1 labeling in the GCL at the end of the BzATP stimulation. The marked regions correspond to the fluorescence traces shown in $A$. C, The cell nuclei were labeled with Hoechst 33342 dye (in red) before the experiment. D, Y0-PRO-1 accumulation (in blue) was induced by prolonged stimulation with BzATP. E, Merged image of $C$ and $D$; the white arrows point out the coincidence between Y0-PRO-1 staining and labeled cell nuclei in the GCL. Scale bars, $50 \mu \mathrm{m}$. a.u., Arbitrary units.

were mostly localized in the two inner rows facing the IPL. As seen already in $\mathrm{P} 2$ rats, a row of cells that manifested clear labeling was detected at the outer limit of the INL. In addition, at P7, the receptor was localized in neuronal processes within the outer plexiform layer (OPL). The location and morphology of staining suggested that the labeled cells were horizontal cells.

The distribution and expression of $\mathrm{P} 2 \mathrm{X}_{7}$ did not change with further retinal development. The IR pattern at P14 (Fig. 1C) resembled that observed at P7 and in adult animals from our previous study (Braendle et al., 1998b).

As mentioned in Materials and Methods, this immunological pattern was obtained using at least three different $\mathrm{P}_{2} \mathrm{X}_{7}$ antibodies directed to different epitopes.

\section{$\mathrm{P} 2 \mathrm{X}_{7}$ activation in the intact rat retina}

Freshly isolated whole-mount rat retinal preparations with the GCL exposed to flowing saline were used to examine the ability of $\mathrm{P} 2 \mathrm{X}_{7}$ to induce cell permeabilization. As an indicator of cell permeabilization, we used the fluorescent dye YO-PRO-1 (molecular weight, $375 \mathrm{Da}$ ). The dye enters the cells only through large pores like those opened by prolonged or sustained stimulation of the $\mathrm{P} 2 \mathrm{X}_{7}$ receptor (Surprenant et al., 1996; Rassendren et al., 1997). After entering a cell, YO-PRO-1 binds to DNA, thus providing stable labeling of the activated cells.

The dye YO-PRO-1 $(1.5 \mu \mathrm{M})$ was added to the medium, and its fluorescence was recorded (Fig. 2A). A small increase in basal fluorescence was detected and recorded for $10 \mathrm{~min}$, during which a stable steady-state level was reached. At that time, the most potent $\mathrm{P}_{2} \mathrm{X}_{7}$ receptor agonist BzATP $(100 \mu \mathrm{M})$ was applied together with the dye. A few seconds after the beginning of stimulation, hot spots of increased fluorescence were detected at different locations in the tissue (Fig. $2 B$ ). Figure $2 A$ shows the time course of fluorescence increases in different regions during a typical experiment $(n=32)$ compared with the negligible increase in baseline fluorescence (Fig. $2 \mathrm{~A}$, trace 6 ). Figure $2 B$ shows the spatial distribution of the fluorescence hot spots at the end of a 10 min stimulation with BzATP. The fluorescent image was overlaid on a bright-field image of the same preparation that revealed the morphological features of the selected focal plane, in this case the GCL. The intracellular locations of the fluorescence spots were confirmed by two different observations. First, a washout of the agonist and YO-PRO- 1 at the end of the experiment had no effect on the intensity or location of the fluorescent hot spots in the tissue, indicating that the dye had not accumulated in the extracellular space (Fig. 2A). Second, retinal cell nuclei were labeled in vivo before agonist stimulation, by incubating the intact retina with the cell membrane-permeable dye Hoechst 33342 $(10 \mu \mathrm{g} / \mathrm{ml})$. As illustrated in Figure $2 C$, the cell nuclei in the GCL were labeled (in red for illustration purposes, to distinguish the fluorescence of Hoechst, excited in the UV range, from that of YO-PRO-1, excited by blue light). After perfusion of YO-PRO-1 and BzATP as just described, many hot spots of fluorescence were identified (Fig. $2 D$, blue). The overlay of Figure $2 C$ with Figure $2 D$ confirms the localization of the YO-PRO-1 staining within cell nuclei.

\section{Pharmacological characterization of retinal cell permeabilization}

To investigate whether a receptor-mediated process induced YOPRO-1 uptake, we studied the effect of different concentrations of agonist on retinal cell permeabilization. BzATP at concentrations as low as $1 \mu \mathrm{M}(n=5)$ did not elicit any cell permeabilization on preparations that were fully responsive to $100 \mu \mathrm{M}$ (Fig. $3 A)$. Moreover, there was no significant increase in fluorescence signals $(n=5)$ (Fig. 3B) with $10 \mu \mathrm{M}$ BzATP. However, further elevation of BzATP to $100 \mu \mathrm{M}$ resulted in a significant increase in YO-PRO-1 fluorescence, indicating a cellular uptake of the dye by activation of $\mathrm{P} 2 \mathrm{X}_{7}$ receptors.

To show that the dose of BzATP necessary to induce cell permeabilization does not exert a toxic and thus nonspecific effect on retinal preparations, inhibitors of $\mathrm{P} 2$ receptors were used to counteract the BzATP effect.

Suramin $(100 \mu \mathrm{M})$ was applied $10 \mathrm{~min}$ before and during application of BzATP. As shown in Figure 3C, we observed no uptake of YO-PRO-1 in the presence of suramin applied with BzATP. However, many cells were permeabilized after suramin was washed out from the saline and BzATP was applied a second time. The result was reproducible in different retinal preparations $(n=4)$, and only one cell responded to the application of BzATP in the presence of suramin.

The same stimulation protocol was used with another P2 receptor antagonist, PPADS $(100 \mu \mathrm{M})$. Again, no BzATPinduced cell permeabilization occurred in the presence of PPADS, as shown in Figure 3D. In contrast to suramin action, 
A

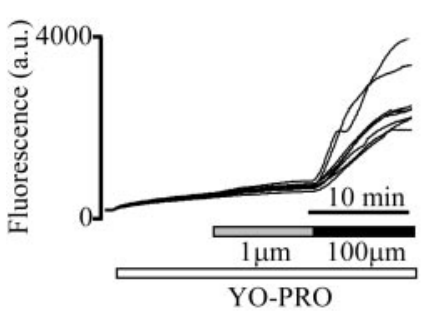

$\mathrm{C}$

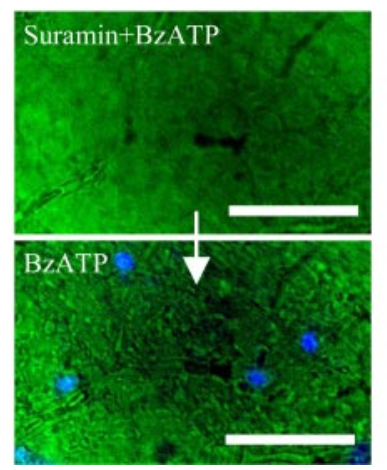

B

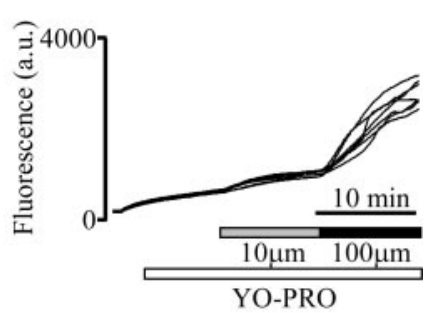

$\mathrm{D}$

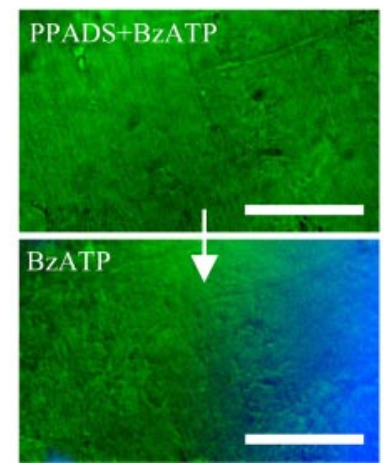

Figure 3. Pharmacology of cell permeabilization. $A, B$, Different doses of BzATP were assessed for their ability to stimulate uptake of the dye Y0-PRO-1 in retinal cells. C, D, Two different purinergic receptors antagonists, suramin and PPADS (100 $\mu \mathrm{m})$, inhibited BzATP-induced cell permeabilization. As expected, and in contrast to suramin, the effect of PPADS was irreversible. Scale bars, $50 \mu \mathrm{m}$. a.u., Arbitrary units.

however, the PPADS effect was irreversible after up to $30 \mathrm{~min}$ of washout $(n=3)$.

Unfortunately, we were unable to verify the action of the most potent antagonist of $\mathrm{P}_{2} \mathrm{X}_{7}$ receptor, OzATP (Murgia et al., 1993). Application of this compound to rat retinal preparations induced permeabilization of almost all of the retinal cells in the absence of BzATP. This effect was already evident 5 min after the beginning of perfusion of the antagonist. It has been shown previously that OzATP can exert toxic effects on cultured rat cerebellar neurons, although this effect was manifested after prolonged incubation, approximately hours, with the compound (Craighead et al., 2001).

Altogether, we were able to verify the inhibitory action of another selective blocker of rat $\mathrm{P} 2 \mathrm{X}_{7}$, namely Brilliant Blue $\mathrm{G}$ (Jiang et al., 2000). The inhibitor was applied $20 \mathrm{~min}$ before application of BzATP $(50-100 \mu \mathrm{M})$ and was effective at both 0.1 $(n=3)$ and $1(n=5) \mu \mathrm{M}$ concentrations. As expected, the inhibition was irreversible after extensive (up to $20 \mathrm{~min}$ ) washout of the compound.

Once the permeabilizing action of BzATP had definitely been ascribed to a receptor-mediated process, we investigated whether other known $\mathrm{P} 2$ receptor agonists were also able to induce cell permeabilization on retinal preparations. ATP, ATP $\gamma \mathrm{S}$, ADP, and UTP were applied respectively with YO-PRO-1. The permeabilizing effect of these compounds was compared in the same preparation with that elicited by BzATP $(100 \mu \mathrm{M})$ when subsequently applied alone. Even at concentrations of $1 \mathrm{~mm}, \operatorname{ADP}(n=$ $3)$, $\operatorname{UTP}(n=3)$, and ATP $\gamma \mathrm{S}(n=3)$ were unable to induce cell permeabilization, indicating that other $\mathrm{P} 2 \mathrm{X}$ subunits do not exert a permeabilizing effect on retinal cells (data not shown). Only ATP concentrations of up to $500 \mu \mathrm{M}(n=8)$ were able to reproduce the fluorescence pattern elicited by BzATP and occlude further activation by BzATP (data not shown). Both of these effects

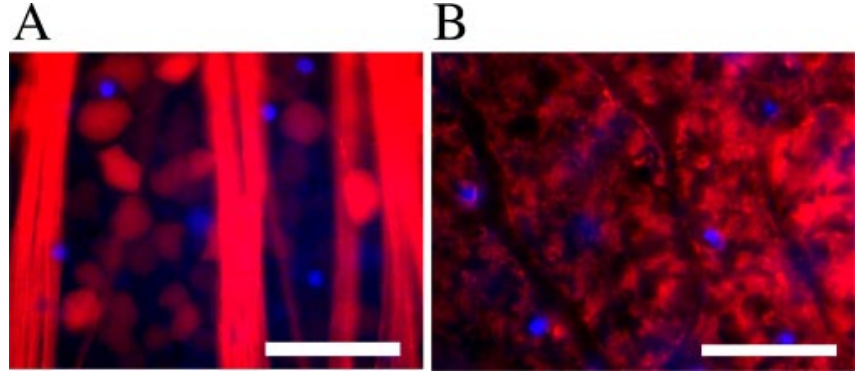

Figure 4. BzATP does not permeabilize RGCs and Muller cells. A, RGCs were labeled with micro-ruby (red). Crystals of the dye were applied on the nerve stump of dissected eyeballs for $15 \mathrm{~min}$. After washout, the retina was dissected and kept for $2 \mathrm{hr}$ at $32^{\circ} \mathrm{C}$ to allow retrograde transport of the dye to the RGC bodies. When Y0-PRO-1 and BzATP were applied, no microruby-labeled cells allowed the entry of Y0-PRO-1 (blue). $B$, Muller cells were labeled by perfusion of red Mitotracker $(10 \mathrm{mg} / \mathrm{ml})$ for $2 \mathrm{~min}$ in the extracellular saline. Bright-stained Muller cell end feet (red) in the ganglion cell layer do not overlay with the Y0-PRO-1 labeling (blue) induced by BzATP stimulation. Scale bars, $50 \mu \mathrm{m}$.

might have been expected from the known pharmacological profile of the $\mathrm{P} 2 \mathrm{X}_{7}$ subunit. Because ADP, UTP, and ATP $\gamma \mathrm{S}$ are only weak ligands for the $\mathrm{P} 2 \mathrm{X}_{7}$ subunit, they were not potent enough to induce $\mathrm{P} 2 \mathrm{X}_{7}$-mediated cell permeabilization. In addition, and in contrast to other $\mathrm{P} 2$ subunits, $\mathrm{P} 2 \mathrm{X}_{7}$ exhibits only a low affinity for ATP and ATP-like agonists (North and Surprenant, 2000).

It is well known that the activity of $\mathrm{P} 2 \mathrm{X}_{7}$ is partially blocked by divalents such as $\mathrm{Ca}^{2+}$ and $\mathrm{Mg}^{2+}$. To maximize receptor activation and thus our ability to detect it, the experiments were generally performed in extracellular saline containing low concentrations of divalent cations $\left(\mathrm{Ca}^{2+}\right.$ at $0.3 \mathrm{~mm}$ and $\mathrm{Mg}^{2+}$ at $\left.0 \mathrm{~mm}\right)$. However, BzATP was still able to induce cell permeabilization, even in the presence of $2 \mathrm{mM} \mathrm{Ca}^{2+}$ and $1 \mathrm{mM} \mathrm{Mg}^{2+}(n=8)$.

\section{Identification of the retinal cell types expressing $\mathrm{P} 2 \mathrm{X}_{7}$}

To identify the retinal cell types permeabilized by ATP, we labeled each cell type before the imaging experiments with cell-specific markers.

RGCs were labeled by retrograde labeling with micro-ruby. After dissection of the eyeballs, a crystal of micro-ruby was applied to the top of the nerve stump. This operation ensured that only RGCs were exposed to the dye. Figure $4 A$ shows a typical preparation in which both the fibers and numerous RGC bodies were labeled (red). After perfusion of YO-PRO-1 and BzATP, there was no colocalization of YO-PRO-1 fluorescence (blue) with micro-ruby-labeled RGCs, indicating that no permeabilization had taken place. Micro-ruby did not diffuse away from pores opened by BzATP, because the molecular weight of the dye (3000 $\mathrm{Da}$ ) is higher than the cutoff size of permeating compounds (Surprenant et al., 1996; Rassendren et al., 1997). Moreover, careful comparison of the labeled RGCs before and after the permeabilizing assay revealed no loss of the dye from the cells.

Figure $4 B$ shows that BzATP failed to induce permeabilization of Muller cells, too. Because of their high phagocytic activity, Muller cells were labeled with a dye (Mitotracker) that was simply added to the external medium for few minutes. Avid uptake of the compound by the exposed Muller cell end feet allowed their identification in the whole-mount preparation (Fig. $4 B$, red). When YO-PRO-1 and BzATP were applied on whole-mount retinas in which Muller cells were labeled, we observed no uptake of YOPRO-1 by the end feet of Muller cells (Fig. $4 B$, blue).

Microglial cells were labeled with Cy3-coupled ILB-4, an isolectin that binds to specific terminal D-galactosyl residues present on the plasma membrane of microglial cells (Streit and 

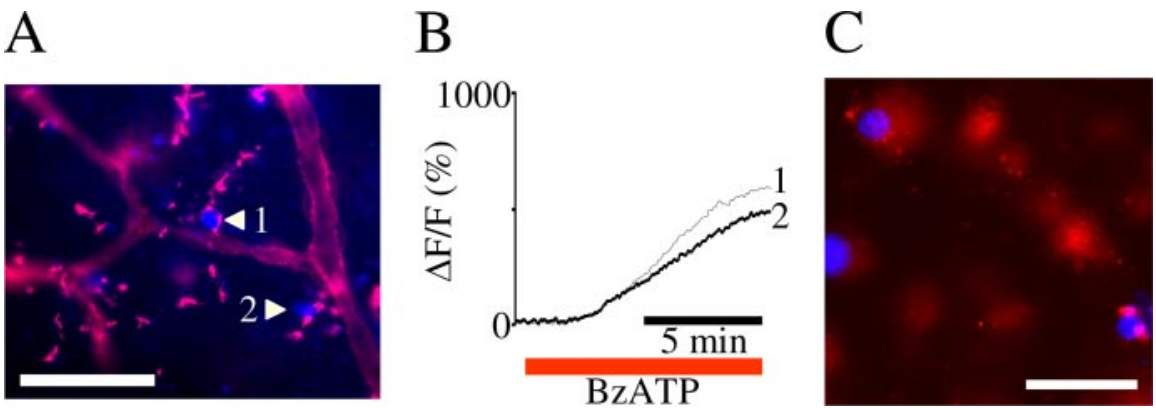

Figure 5. Microglial cells are permeabilized by BzATP stimulation. A shows a retinal preparation in which microglial cells were labeled by incubation of flat-mount retinas with Cy3-conjugated ILB-4 (red; $20 \mathrm{mg} / \mathrm{ml}, 1 \mathrm{hr}$ at $32^{\circ} \mathrm{C}$ ) before the experiment. At the end of the experiment, two ILB-4-labeled cells were labeled by Y0-PRO-1 (blue). The graph in $B$ shows the kinetics of specific Y0-PRO-1 uptake after activation with BzATP at $100 \mu \mathrm{m}$. The traces refer to the same two bead-labeled cells shown in $A$. In $C$, several cells in the $\mathrm{GCL}$ are labeled by red fluorescent beads. The fluorescent beads were injected in P1 rat superior colliculus, in which the majority of ganglion cell axons terminate. However, in the first week of retinal development, many RGCs die, and microglial cells phagocyte dying RGCs and thus uptake the fluorescent beads as well. Two bead-labeled cells clearly uptook Y0-PR0-1 during BzATP stimulation. Because, as we have already shown, RGCs are not permeabilized by BzATP, the two labeled cells were identified as microglial cells that had ingested labeled RGCs. Scale bars, $50 \mu \mathrm{m}$.

Kreutzberg, 1987; Streit, 1990). As shown in Figure 5A, ILB-4 labeling revealed the ramified morphology typical of resting microglial cells (red). After perfusion of YO-PRO-1 and BzATP, the nuclei of two cells that were delimited by the ILB-4 IR appeared (Fig. $5 A$, blue). The relative spatial localization of the fluorescent signals suggested that YO-PRO-1 entered in two prelabeled microglial cells. Figure $5 B$ shows the kinetics of the fluorescence increases, proving the specificity of the signal for the addition of BzATP. The traces refer to the same two microglial cells shown in Figure $5 \mathrm{~A}$.

In Figure $5 A$, it is apparent that ILB-4 labeled not only microglial cells but also the endothelium of blood vessels (Streit et al., 1987). To substantiate the identification of microglial cells as targets of cell permeabilization by $\mathrm{P} 2 \mathrm{X}_{7}$ stimulation, we used an additional labeling procedure.

Red fluorescent beads were injected into the superior colliculus of $\mathrm{P} 1$ animals. The beads were transported retrogradely to the RGC. During the first 2 weeks of rat retinal development, many RGCs die as a result of natural apoptosis (Cellerino et al., 2000) and are phagocytozed by microglial cells. Thus, microglial cells that ingested bead-labeled dying RGCs become labeled as well (Bodeutsch and Thanos, 2000).

BzATP and YO-PRO-1 were applied to retinas with a mixed population of RGCs and microglial cells labeled with red fluorescent beads. Uptake of YO-PRO-1 was detected in a few beadlabeled cells (Fig. 5C). Because we have shown previously that RGCs are not permeabilized by BzATP stimulation, the permeabilized cells can only have been microglial cells that had previously phagocytozed dying RGCs.

In conclusion, our data clearly indicate that, despite the widespread expression of $\mathrm{P} 2 \mathrm{X}_{7}$ subunits in different neuronal types in the inner rat retina, prolonged stimulation of this subunit elicits permeabilization only in microglial cells located in the nerve fiber layer, in close proximity to RGC.

\section{Discussion}

Among P2X receptors, the $\mathrm{P} 2 \mathrm{X}_{7}$ subtype holds a special position because of its ability to act as both a classical, ligand-gated ion channel and a permeabilization pore that can induce cell death under prolonged activation by ATP (Ferrari et al., 1997, 1999; Virginio et al., 1999; Di Virgilio et al., 2001). Because we have shown previously that $\mathrm{P} 2 \mathrm{X}_{7}$ receptors are expressed in the inner retina, including retinal neurons (Braendle et al., 1998b), the aim of the present study was to assess whether the $\mathrm{P} 2 \mathrm{X}_{7}$ subtype can induce permeabilization of retinal cells in response to prolonged activation by ATP and to identify the cell types affected.

The results of this study suggest that the receptor is not only present at developmental stages as early as $\mathrm{P} 2$ but is also functionally active. Cell permeabilization was found only in microglial cells that are located close to RGCs in the nerve fiber layer.

\section{Experimental approach}

Fluorescence assay of cell permeabilization was chosen for experiments performed on freshly excised retinas in whole-mount preparation with a minimum of manipulation before the experiments. Vertical slices were not suitable because of extended cell damage at the surfaces during preparation. Cells that were dying after damage or that were stimulated by ATP from adjacent dying cells would have taken up the dye, halting our ability to assess the specificity of the uptake by controlled $\mathrm{P} 2 \mathrm{X}_{7}$ stimulation.

We made also a careful choice of the age of the animals to be used. We opted for animals in the first 2 weeks of postnatal development for several reasons. (1) Almost 50\% of RGCs die during the first 2 weeks of rat retinal development, before definitive connections to the brain are established. If the $\mathrm{P} 2 \mathrm{X}_{7}$ receptor were indeed involved in mediating RGC death by induction of cell permeabilization, our ability to detect cell activation would have been favored by using early postnatal stages. (2) During early postnatal development, the nerve fiber layer is relatively thin, which would ensure a better penetration of the chemical compounds we were using. At later stages, we should have used enzymatic treatment to penetrate the nerve fiber layer and allow the diffusion of the chemicals deep into the retinal tissue, increasing the possibility of inducing unwanted cell damage.

\section{Pharmacology of $\mathrm{P} 2 \mathrm{X}_{7}$ receptor}

Once we had defined the proper experimental model, we applied YO-PRO-1 as a marker of cell permeabilization together with BzATP, the most potent agonist of $\mathrm{P} 2 \mathrm{X}_{7}$ receptors.

BzATP can stimulate $\mathrm{P} 2 \mathrm{X}_{1}, \mathrm{P} 2 \mathrm{X}_{3}$, and $\mathrm{P} 2 \mathrm{Y}$ receptors as well (Bianchi et al., 1999; Pannicke et al., 2000). However, we have shown previously that the rat retina does not express $\mathrm{P} 2 \mathrm{X}_{1}$ (Braendle et al., 1998a). Moreover, even if other P2 subunits have been shown to induce cell permeabilization, $\mathrm{P} 2 \mathrm{X}_{1}$ and $\mathrm{P} 2 \mathrm{X}_{3}$ are not among them (Khakh et al., 1999; Virginio et al., 1999).

Among the different purinergic receptor agonists we used in this study, only ATP and BzATP elicited YO-PRO-1 uptake. ADP and UTP, agonists of P2Y receptors, were ineffective, suggesting that $\mathrm{P} 2 \mathrm{Y}$ receptors were not involved in cell permeabilization.

The generic purinergic antagonists suramin and PPADS inhibited cell permeabilization. This observation was important, because it excluded the possibility that another subtype, $\mathrm{P}_{4} \mathrm{X}_{4}$, could be involved in cell permeabilization. $\mathrm{P}_{2} \mathrm{X}_{4}$ can induce cell permeabilization in transfected cells under prolonged receptor stimulation. However, the receptor is not sensitive to the action of the aforementioned inhibitors (North and Surprenant, 2000). In addition, YO-PRO- 1 entry by $\mathrm{P}_{2} \mathrm{X}_{4}$ has much slower kinetics 
and less probability to occur than that by $\mathrm{P} 2 \mathrm{X}_{7}$ (Khakh et al., 1999). Instead, the time course of cell permeabilization we observed matches the one expected for $\mathrm{P}_{2} \mathrm{X}_{7}$ receptor.

In further support for a $\mathrm{P} 2 \mathrm{X}_{7}$-mediated cell permeabilization, YO-PRO-1 entry was blocked by Brilliant Blue G, a selective inhibitor of rat $\mathrm{P} 2 \mathrm{X}_{7}$ receptor. The effect was observed at nanomolar concentrations of inhibitor, even in the tissue preparations we used in our experiments.

Unexpectedly, we were unable to examine the action of the best-known $\mathrm{P}_{2} \mathrm{X}_{7}$ antagonist, OzATP. The compound had a fast and wide neurotoxic effect on retinal preparations, inducing nonspecific permeabilization and thus YO-PRO-1 uptake in all cells in the inner retina in $<5 \mathrm{~min}$ of stimulation. Whether this phenomenon is attributable to a tissue-specific effect needs to be explored further.

\section{Identification of retinal cell types expressing permeabilizing $\mathrm{P}_{2} \mathrm{X}_{7}$}

To find which retinal cell types expressed functional $\mathrm{P} 2 \mathrm{X}_{7}$ receptors, we used live staining for the different cell types.

Muller cells did not manifest any phagocytic activity for YOPRO-1 under resting or ATP/BzATP-stimulated conditions. It might be objected here that Muller cell nuclei lie deep in the INL, so that the binding of the dye to DNA could pass undetected in experiments like ours in which the focal plane is located in the ganglion cell layer. However, we have already shown that rat Muller cells do not express the $\mathrm{P}_{2} \mathrm{X}_{7}$ subunit (Jabs et al., 2000), and preliminary experiments of double immunostaining with antibodies against $\mathrm{P} 2 \mathrm{X}_{7}$ and glutamine synthethase fully support the observation that $\mathrm{P} 2 \mathrm{X}_{7}$ is not expressed by rat Muller cells.

Regarding the second glial cell type in the retina, astrocytes, our study found no evidence of the expression of "pore-forming" $\mathrm{P}_{2} \mathrm{X}_{7}$. There is evidence that astrocytes express $\mathrm{P} 2 \mathrm{X}_{7}$ both in culture and in situ (Ballerini et al., 1996; Kukley et al., 2001). However the size and shape of the nuclei that took up YO-PRO-1 in our study did not match with the large and oval shape of the nuclei belonging to astrocytes. In addition, no colocalization between GFAP and $\mathrm{P}_{2} \mathrm{X}_{7}$ was detected in preliminary immunofluorescence experiments.

In a previous study, using single-cell reverse transcriptionPCR and immunohistochemical techniques, we found evidence for the expression of $\mathrm{P} 2 \mathrm{X}_{7}$ receptors in at least a subpopulation of RGCs (Braendle et al., 1998b). In the present study, receptor activation failed to induce pore permeabilization in RGS. The two sets of experiments are not in opposition to each other. The fluorescence imaging approach of the present study aimed at detecting only a specific operating mode of $\mathrm{P} 2 \mathrm{X}_{7}$, namely the permeabilizing pore state induced by prolonged agonist stimulation rather than its function as a ligand-gated ion channel. It is thus possible that RGCs or a subpopulation of them express functional $\mathrm{P} 2 \mathrm{X}_{7}$ receptors acting as "classical ionic channels." To verify this hypothesis, we are performing electrophysiological patchclamp recordings from identified RGCs in intact tissue.

Several research groups have shown that $\mathrm{P}_{2} \mathrm{X}_{7}$ is expressed and functionally active in the RGCs of different animal species (Davies and Baldridge, 2001; Zhang et al., 2002; Ishii et al., 2003). Independently of the lack of permeabilizing activity, $\mathrm{P} 2 \mathrm{X}_{7}$ subunit activation may induce cytotoxicity through prolonged calcium influx (Zhang et al., 2002) or through stimulation of release of neurotoxic compounds. In the CNS, $\mathrm{P}_{2} \mathrm{X}_{7}$ receptor activation has been reported to enhance glutamate release from presynaptic terminals and cultured astrocytes (Deuchars et al., 2001; Ye et al.,
2003). Additional studies will be aimed at identifying the role of $\mathrm{P}_{2} \mathrm{X}_{7}$ in RGCs.

Our study indicated that cell permeabilization was induced by $\mathrm{P}_{2} \mathrm{X}_{7}$ activation only in microglial cells. It is known that ATP activates $\mathrm{P}_{2} \mathrm{X}_{7}$ receptors in microglial cells in which it mediates cytotoxic responses and cytokine release. This suggests that it may have an important role in immunomodulation (Collo et al., 1997; Di Virgilio et al., 1998; Ferrari et al., 2000; Inoue, 2002). There is increasing evidence that microglial cells are related to a number of physio-pathological events in the retina when massive cell death occurs (Schnitzer and Scherer, 1990; Milligan et al., 1991; Thanos, 1991; Frade and Barde, 1998). Their role is not restricted to a mere removal of damaged and dying neurons. Microglia contribute actively to the degradation of neurons, because it has been shown that suppression of microglial activity results in a retardation of tissue cell death (Thanos et al., 1993; Frade and Barde, 1998).

Because $\mathrm{P}_{2} \mathrm{X}_{7}$ activation is the major trigger of microglial activation, $\mathrm{P}_{2} \mathrm{X}_{7}$ may indeed play a role in retinal cell death. In response to stimulation, microglia release ATP, nitric oxide, tumor necrosis factor- $\alpha$, interleukin- $1 \beta$, and other compounds (Chao et al., 1992; Hide et al., 2000; Sanz and Di Virgilio, 2000) which may contribute to neuronal cell death. In addition, microglial cells interact with various other cell types, which in turn can affect neurons, including astrocytes (Verderio and Matteoli, 2001; John et al., 2003) and Muller cells (Harada et al., 2002).

Recently, another group provided evidence that $\mathrm{P} 2 \mathrm{X}_{7}$ activation induces permeabilization of retinal pericytes in microvessels freshly isolated from the adult rat retina (Kawamura et al., 2003). Difference in the kinetics and intensity of the uptake of YOPRO-1 between microglia and pericytes could explain why YOPRO-1 uptake in pericytes was undetected in our experiments.

In conclusion, we demonstrated that $\mathrm{P}_{2} \mathrm{X}_{7}$ receptors are expressed and functionally active during development of the mammalian retina. A discrepancy between the distribution of the receptor subunit and its permeabilizing activity suggests that the receptor has different activation properties in different retinal cell types, and thus $\mathrm{P}_{2} \mathrm{X}_{7}$ may be involved in multiple physiological and pathological states of the mammalian retina.

\section{References}

Ballerini P, Rathbone MP, Di Iorio P, Renzetti A, Giuliani P, D’Alimonte I, Trubiani O, Caciagli F, Ciccarelli R (1996) Rat astroglial P2Z (P2X7) receptors regulate intracellular calcium and purine release. NeuroReport 7:2533-2537.

Bianchi BR, Lynch KJ, Touma E, Niforatos W, Burgard EC, Alexander KM, Park HS, Yu H, Metzger R, Kowaluk E, Jarvis MF, van Biesen T (1999) Pharmacological characterization of recombinant human and rat P2X receptor subtypes. Eur J Pharmacol 376:127-138.

Bodeutsch N, Thanos S (2000) Migration of phagocytotic cells and development of the murine intraretinal microglial network: an in vivo study using fluorescent dyes. Glia 32:91-101.

Braendle U, Guenther E, Irrle C, Wheeler-Schilling TH (1998a) Gene expression of the P2X receptors in the rat retina. Mol Brain Res 59:269-272.

Braendle U, Kohler K, Wheeler-Schilling TH (1998b) Expression of the P2X7-receptor subunit in neurons of the rat retina. Mol Brain Res 62:106-109.

Cellerino A, Bahr M, Isenmann S (2000) Apoptosis in the developing visual system. Cell Tissue Res 301:53-69.

Chao CC, Hu S, Molitor TW, Shaskan EG, Peterson PK (1992) Activated microglia mediate neuronal cell injury via a nitric oxide mechanism. J Immunol 149:2736-2741.

Collo G, Neidhart S, Kawashima E, Kosco-Vilbois M, North RA, Buell G (1997) Tissue distribution of the P2X7 receptor. Neuropharmacology 36:1277-1283.

Craighead MW, Middlehurst KM, LeFeuvre R, Kimber I, Rothwell NJ (2001) 
Oxidised adenosine $5^{\prime}$-triphosphate, a P2X(7) antagonist, is toxic to rat cerebellar granule neurones in vitro. Neurosci Lett 311:77-80.

Davies MD, Baldridge WH (2001) P2X3 and P2X7 receptor localization on cholinergic amacrine cells in mammalian retina. Soc Neurosci Abstr 27:284.9.

Deuchars SA, Atkinson L, Brooke RE, Musa H, Milligan CJ, Batten TF, Buckley NJ, Parson SH, Deuchars J (2001) Neuronal P2X $\mathrm{X}_{7}$ receptors are targeted to presynaptic terminals in the central and peripheral nervous systems. J Neurosci 21:7143-7152.

Di Virgilio F, Falzoni S, Mutini C, Sanz JM, Chiozzi P (1998) Purinergic P2X7 receptor: a pivotal role in inflammation and immunomodulation. Drug Dev Res 45:207-213.

Di Virgilio F, Vishwanath V, Ferrari D (2001) On the role of P2X7 receptor in the immune system. In: Purinergic and pyrimidinergic signaling ( $\mathrm{Ab}-$ bracchio MP, Williams M, eds), pp 355-374. Heidelberg: Springer.

Ferrari D, Chiozzi P, Falzoni S, Dal Susino M, Collo G, Buell G, Di Virgilio F (1997) ATP-mediated cytotoxicity in microglial cells. Neuropharmacology 36:1295-1301.

Ferrari D, Los M, Bauer MK, Vandenabeele P, Wesselborg S, Schulze-Osthoff K (1999) P2Z purinoreceptor ligation induces activation of caspases with distinct roles in apoptotic and necrotic alterations of cell death. FEBS Lett 447:71-75.

Ferrari D, La Sala A, Chiozzi P, Morelli A, Falzoni S, Girolomoni G, Idzko M, Dichmann S, Norgauer J, Di Virgilio F (2000) The P2 purinergic receptors of human dendritic cells: identification and coupling to cytokine release. FASEB J 14:2466-2476.

Frade JM, Barde YA (1998) Microglia-derived nerve growth factor causes cell death in the developing retina. Neuron 20:35-41.

Harada T, Harada C, Kohsaka S, Wada E, Yoshida K, Ohno S, Mamada H, Tanaka K, Parada LF, Wada K (2002) Microglia-Muller glia cell interactions control neurotrophic factor production during light-induced retinal degeneration. J Neurosci 22:9228-9236.

Hide I, Tanaka M, Inoue A, Nakajima K, Kohsaka S, Inoue K, Nakata Y (2000) Extracellular ATP triggers tumor necrosis factor-alpha release from rat microglia. J Neurochem 75:965-972.

Inoue K (2002) Microglial activation by purines and pyrimidines. Glia 40:156-163.

Ishii K, Kaneda M, Li H, Rockland KS, Hashikawa T (2003) Neuron-specific distribution of $\mathrm{P} 2 \mathrm{X} 7$ purinergic receptors in the monkey retina. J Comp Neurol 459:267-277.

Jabs R, Guenther E, Marquordt K, Wheeler-Schilling TH (2000) Evidence for $\mathrm{P} 2 \mathrm{X} 3, \mathrm{P} 2 \mathrm{X} 4, \mathrm{P} 2 \mathrm{X} 5$ but not for $\mathrm{P} 2 \mathrm{X} 7$ containing purinergic receptors in Muller cells of the rat retina. Mol Brain Res 76:205-210.

Jiang LH, Mackenzie AB, North RA, Surprenant A (2000) Brilliant blue G selectively blocks ATP-gated rat $\mathrm{P} 2 \mathrm{X}(7)$ receptors. Mol Pharmacol 58:82-88

John GR, Lee SC, Brosnan CF (2003) Cytokines: powerful regulators of glial cell activation. The Neuroscientist 9:10-22.

Kawamura H, Sugiyama T, Wu DM, Kobayashi M, Yamanishi S, Katsumura K, Puro DG (2003) ATP: a vasoactive signal in the pericyte-containing microvasculature of the rat retina. J Physiol (Lond) 551:787-799.

Keirstead SA, Miller RF (1997) Metabotropic glutamate receptor agonists evoke calcium waves in isolated Muller cells. Glia 21:194-203.

Khakh BS, Bao XR, Labarca C, Lester HA (1999) Neuronal P2X transmittergated cation channels change their ion selectivity in seconds. Nat Neurosci 2:322-330.

Kirischuk S, Scherer J, Kettenmann H, Verkhratsky A (1995) Activation of $\mathrm{P} 2$-purinoreceptors triggered $\mathrm{Ca}^{2+}$ release from InsP3-sensitive internal stores in mammalian oligodendrocytes. J Physiol (Lond) 483:41-57.

Kukley M, Barden JA, Steinhauser C, Jabs R (2001) Distribution of P2X receptors on astrocytes in juvenile rat hippocampus. Glia 36:11-21.

Milligan CE, Levitt P, Cunningham TJ (1991) Brain macrophages and microglia respond differently to lesions of the developing and adult visual system. J Comp Neurol 314:136-146.

Murgia M, Hanau S, Pizzo P, Rippa M, Di Virgilio F (1993) Oxidized ATP.
An irreversible inhibitor of the macrophage purinergic P2Z receptor. J Biol Chem 268:8199-8203.

Neal MJ, Cunningham JR (1994) Modulation by endogenous ATP of the light-evoked release of Ach from retinal cholinergic neurons. Br J Pharmacol 113:1085-1087.

Neal MJ, Cunningham JR, Dent Z (1998) Modulation of extracellular GABA levels in the retina by activation of glial P2X-purinoceptors. Br J Pharmacol 124:317-322.

Newman EA (2001) Propagation of intercellular calcium waves in retinal astrocytes and Muller cells. J Neurosci 21:2215-2223.

Newman EA, Zahs KR (1997) Calcium waves in retinal glial cells. Science 275:844-847.

Newman EA, Zahs KR (1998) Modulation of neuronal activity by glail cells in the rat retina. J Neurosci 18:4022-4028.

North RA, Surprenant A (2000) Pharmacology of cloned P2X receptors. Annu Rev Pharmacol Toxicol 40:563-580.

Pannicke T, Fischer W, Biedermann B, Schadlich H, Grosche J, Faude F, Wiedemann P, Allgaier C, Illes P, Burnstock G, Reichenbach A (2000) $\mathrm{P} 2 \mathrm{X} 7$ receptors in Muller glial cells from the human retina. J Neurosci 20:5965-5972.

Ralevic V, Burnstock G (1998) Receptors for purines and pyrimidines. Pharmacol Rev 50:413-492.

Rassendren F, Buell G, Virginio C, Collo G, North RA, Suprenant A (1997) The permeabilizing ATP receptor P2X7: cloning of a human cDNA. J Biol Chem 272:5482-5486.

Sanz JM, Di Virgilio F (2000) Kinetics and mechanism of ATP-dependent IL-1 beta release from microglial cells. J Immunol 164:4893-4898.

Schnitzer J, Scherer J (1990) Microglial cell responses in the rabbit retina following transection of the optic nerve. J Comp Neurol 302:779-791.

Streit WJ (1990) An improved staining method for rat microglial cells using the lectin from Griffonia simplicifolia (GSA I-B4). J Histochem Cytochem 38:1683-1686.

Streit WJ, Kreutzberg GW (1987) Lectin binding by resting and reactive microglia. J Neurocytol 16:249-260.

Surprenant A, Rassendren F, Kawashima E, North RA, Buell G (1996) The cytolytic P2Z receptor for extracellular ATP identified as a $\mathrm{P} 2 \mathrm{X}$ receptor (P2X7). Science 272:735-738.

Taschenberger H, Jutter R, Grantyn R (1999) $\mathrm{Ca}^{2+}$-permeable P2X receptor channels in cultured rat retinal ganglion cell. J Neurosci 19:3353-3366.

Thanos S (1991) The relationship of microglial cells to dying neurons during natural neuronal cell death and axotomy-induced degeneration of the rat retina. Eur J Neurosci 3:1189-1207.

Thanos S, Mey J, Wild M (1993) Treatment of the adult retina with microglia-suppressing factors retards axotomy-induced neuronal degradation and enhances axonal regeneration in vivo and in vitro. J Neurosci 13:455-466.

Verderio C, Matteoli M (2001) ATP mediates calcium signaling between astrocytes and microglial cells: modulation by IFN-gamma. J Immunol 166:6383-6391.

Virginio C, MacKenzie A, Rassendren FA, North RA, Surprenant A (1999) Pore dilation of neuronal P2X receptor channels. Nat Neurosci 2:315-321.

Wheeler-Schilling TH, Marquordt K, Kohler K, Jabs R, Guenther E (2000) Expression of purinergic receptors in bipolar cells of the rat retina. Brain Res Mol Brain Res 76:415-418.

Wheeler-Schilling TH, Marquordt K, Kohler K, Guenther E, Jabs R (2001) Identification of purinergic receptors in retinal ganglion cells. Mol Brain Res 92:177-180.

Ye ZC, Wyeth MS, Baltan-Tekkok S, Ransom BR (2003) Functional hemichannels in astrocytes: a novel mechanism of glutamate release. J Neurosci 23:3588-3596.

Zhang X, Laties AM, Mitchell CH (2002) Adenosine protects retinal ganglion cells from cytotoxic death following P2X7 receptor stimulation. Invest Ophthalmol Vis Sci 44:5201. 